\title{
legelivet
}

På disse sidene i Tidsskriftet - legelivet - finner du stoff om legers liv.

Her er det presentasjon av arbeidssteder, nyhetssaker, nye doktorgrader,

nye spesialister og minneord. Alt samlet på ett sted - så du kan følge enda bedre med.

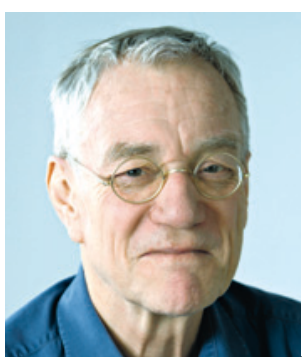

Olaf Gjerløw Aasland.

Foto: Einar Nilsen

Olaf Gjerløw Aasland (f. 1944) er seniorforsker ved LEFO - Legeforskningsinstituttet.

\section{Legen som investeringsobjekt og rollemodell}

En lege er et levende eksempel på hvor god helsen kan bli for den som vet alt om riktig livsstil og sunne levevaner.

Det er ikke mulig å være lege bare i arbeidstiden. Etter helsepersonellovens $\S 7$ om øyeblikkelig hjelp gjelder vårt samfunnsoppdrag «tjuefire-sju». Det er ikke misbruk av vår profesjon når noen over høyttaleren spør om det er en lege til stede. Samfunnet må få litt igjen for sin investering på nesten fem millioner kroner per ferdig lege (1).

Heldigvis står det i paragrafens siste ledd at «Plikten gjelder ikke i den grad annet kvalifisert helsepersonell påtar seg ansvaret for å gi helsehjelpen». Med vel 200 innbyggere per aktive lege er sannsynligheten for at det er flere enn én lege til stede faktisk ganske stor, noe mange av oss har opplevd.

I våre egne sosiale nettverk er det neppe mulig å være yrkesanonym, leger er rollemodeller uansett. Enten vi vil eller ikke er vi levende eksempler på hvor god helsen kan bli for den som vet alt om riktig livsstil og sunne levevaner. Sannsynligvis øker det i seg selv også vår motivasjon for tilstrekkelig fysisk aktivitet og annen forebygging, og at vi holder oss på matta når det gjelder nytelsesmidler.

En fordel med å være så synlige er at røy- kende, rusete eller overvektige leger lettere skiller seg ut. Det er lenge siden en lungelege kunne sitte og røyke under konsultasjonen, men det er ikke lenge siden en ruspåvirket kirurg ble kastet ut av operasjonssalen. Dette handler egentlig om legenes vanskelige vei ned fra pidestallen. Det er en nødvendig nedstigning mot jorden $\mathrm{i}$ et moderne helsevesen der brukermedvirkning - eller kommunikativ styring (2) - vokser frem som et bærende prinsipp. Legen må være enda mer til stede i hverdagen.

Etter min mening skal ikke legen helt ned på jorden, men stå på en etisk skammel med litt bedre oversikt og litt mer ansvar.

\section{Olaf Gjerløw Aasland}

Olaf.aasland@legeforeningen.no

\section{Litteratur}

1. Amundsen B. Hvor mye koster en norsk student? http://forskning.no/2015/08/hvor-mye-koster-ennorsk-student Lest 18.1.2017.

2. Øverbye E. Velferdsprofesjonene i aktiviseringsstaten: en studie av ambivalente relasjoner. I Molander, A. og Smeby, J-C. Profesjonsstudier II. Oslo: Universitetsforlaget, 2013: 107-21. 